\title{
The Vocative Case: Romanian versus Latin
}

\author{
loana Costa \\ University of Bucharest \\ ioana.costa@lls.unibuc.ro
}

Abstract:

\begin{abstract}
The vocative is a residuary case in most Indo-European languages, mirroring a particular Proto-Indo-European status. Its syntactical function is preserved in the descendant languages, but the morphological aspects are strongly simplified. In Latin, not unlike the cognate languages, the general tendency is toward a formal overlapping with the nominative case. The Romanian vocative is, in the Romance frame, surprisingly multifarious. It displays four distinct variants: desinence and intonation; desinence, intonation and prolongation of the final vowel; intonation and vowel prolongation; solely intonation. Old Romanian texts attest the tendency of gradually replacing the vocative form with the nominative form, perceived as more expressive. On the other hand, there is an observable development of the formal marks specific to this syntactical function; these marks are only partially inherited from Latin. In nowadays Romanian language the formal specificity of the vocative case is not diminishing - on the contrary, some colloquial vocative forms (not yet acceptable in the frame of the linguistic norm) emphasize an unambiguous linguistic will to maintain this case, while the general tendency is to reduce as much as possible the differences between the actual two cases of the Romanian language, nominative-accusative and genitive-dative.
\end{abstract}

\section{Introduction}

In the frame of comparative linguistics, the status of the vocative case imposes a definition in terms of a relic case, attesting the Proto-Indo-European stage of the first bifurcation in the name syntax, id est interpellation versus the rest of the nominal functions. The vocative is actually a formal relic and not a syntactic relic: in Latin it displays distinct marks only in a limited part of the thematic declension (the animated nouns ending in -us at the nominative case). The general trend is toward replacing it with the nominative form, syntactically enriched by the interpellation function. This trend has only one exception: the vocative luppiter (composed with the appellative pater, "father", attesting a non-etymological double -pp-, in order to increase the expressivity of this frequently used invocation) that became the regular nominative form in classical Latin); the Latin use of a vocative form with nominative function is comparable with its Romanian lexical equivalent, in baby talk: "Doamne-Doamne" (recurrently used as nominative-accusative).

Some theoretical approaches point out the definition of the vocative case as non-syntactic (Pană Dindelegan 2010, 57) and, in its diachronic alternative, from the perspective of ancient languages, as exclamatory incident free proposition (Sluşanschi 1994, 33). It is somehow close to the syntactic function of the apposition (vide Tomescu 1998, 176), due to the fact that it preserves the independence with respect to the context, even if it receives an attribute or, on the contrary, functions as an apposition of another noun. The vocative communicates a relationship of interdependence with a certain part of the adjoining proposition, given the fact that, if it is to be considered a proposition, the ensemble is structured as two distinct propositions. The formal overlapping of nominative and vocative becomes the linguistic standard in the Romanian language (nevertheless in the frame of comparative linguistics), thanks to the similarities with the apposition.

Beyond the particularities of its syntactic function, the Romanian vocative displays its own formal marks, in four distinct variants: desinence and intonation; desinence, intonation and prolongation of the final vowel; intonation and vowel prolongation; solely intonation.

The occurrences of vocative in Old Romanian texts attest the gradual tendency of replacing the vocative with nominative, considered to be stronger and more explicit. Exempli gratia: in the biblical book of Prophet Ezekiel, the phrase "fiul omului" ("son of human") appears no less than ninety four times in vocative. For a text that stretches on forty eight chapters, this multiplication of one single phrase has all the characteristics of an emblematic message. The meaning of this phrase has been abundantly analyzed, mostly in messianic perspective. The present paper considers its morphosyntactic aspect, regarding predominantly the Romanian translations. For example, the pericope Ez. 2:1 is to be found in the main Romanian biblical translation in these terms: "Fiul omului! Scoală-te în picioare ca să vorbesc cu tine!” (Radu-Galaction, 1939); „Fiul omului, scoală în picioare, că am să-ţi vorbesc!” (Iustinian 1968 /Teoctist 1988); „Fiul omului, ţine-te pe picioarele tale şi-ţi 
voi grăi!” (Anania, 2001); „Fiul omului, stai în picioare, şi-ţi voi vorbi!” (Cornilescu, 2000); „Fiiul omului, stăi pre picioarele tale şi voiu grăi cătră tine.” (Bible of Bucharest, 1688); „Fiiul omului, stăi pre picioarele tale şi voiu grăi cătră tine!” (Bible of Blaj, 1795); „Fiiul omului, stăi pă picioarele tale şi voiu grăi cu tine!” (Vulgata of Blaj, 1760-1761); "Fiu al omului, stai pe picioarele tale şi îţi voi grăi." (Septuaginta, 2008).

The patristic texts largely commented on this phrase, throughout the New Testament occurrences (eighty eight), in a slightly different form, as both the nouns are articulated, "the son of the human", vide the Greek ho hyós toú anthrópou. The phrase ${ }^{1}$ of the book of Ezekiel is constantly associated with the pericope Daniel 7:13-14: "Priveam în vedenie de noapte şi, iată, pe norii cerului venea ca un fiu al omului (Greek hos hyós anthrópou) şi <Cel> ca <unul> vechi de zile se afla acolo, şi cei de faţă s-au apropiat de el. Şi i s-a dat puterea şi toate neamurile pământului, pe seminţii, şi întreaga slavă erau în slujba lui; şi puterea lui [este] putere veşnică, ce nicicând nu va fi luată: şi împărăţia lui nicicând nu se va strica." The text in the Theodotion version displays differencies that do not involve the phrase "son of human": "Priveam în vedenie de noapte şi, iată, cu norii cerului venea ca un fiu al omului (Greek hos hyós anthrópou); şi a înaintat până la Cel vechi de zile şi a fost adus în faţa Lui. Şi i s-a dat domnia şi cinstirea şi împărăţia, şi toate popoarele, seminţiile şi limbile îi vor sluji; puterea lui <este> putere veşnică, ce nu va trece, şi împărăţia lui nu va fi nimicită." (Septuaginta, 2008)

The phrase is again present in the next chapter of the book of Prophet Daniel, 8:17, included in a direct communication, similar to the occurrences in the book of Ezekiel: "[...] şi mi-a zis: «Înţ̧elege, fiu al omului (Greek hyié anthrópou), căci această arătare <este> chiar pentru ceasul vremii cuvenite»"; the Theodotion version attests again the same phrase: "[...] şi <el> a zis către mine: "Pricepe, fiu al omului (Greek hyié anthrópou), căci vedenia <este> chiar pentru sfârşitul vremii.»"(Septuaginta, 2008).

The third noteworthy occurrence in the book of Daniel is 10:11; the pericope does not include neither the phrase "son of human", nor a vocative (although the Theodotion version might include the Greek vocative aner, with short vowel and withdrawn accent, formally replaced by nominative, plausibly under the influence of an ambiguous appellative, Daniel, that lacks any mark of accentuation, as usually happens with the foreign names in Septuagint) - it nevertheless resembles some Ezekiel occurrences, including the exhortation to stay on his own feet: "Şi mi-a spus: «Daniele, eşti un om vrednic de milostivire (Greek ánthropos eleeinós); cugetă la poruncile pe care eu le grăiesc către tine, şi stai pe locul tău, căci tocmai am fost trimis la tine!»»; in this case, the Theodotion version is different: "Şi mi-a spus: "Daniele, bărbat al doririlor (Greek anér epithymión), înţelege cuvintele pe care le voi rosti către tine, şi stai pe picioarele tale, căci acum am fost trimis la tine!»"

In the book of Ezekiel, the phrase "son of human", in vocative (with the specific mark of the case), is attested in situations that might be divided into two series: in the first series, there are the direct commands, with or without the insertion of the personal pronoun, with or without an emphatic order of the words (the vocative in the first or the second position); in the second series are references to "son of human" in phatic expressions, with or without an emphatic order of words (the vocative in the first or the second position).

The direct appealing that observes the pattern: personal pronoun, second singular, and the vocative case, /tu+vocative/, is always used with a mark of coordination, as these are frequently exhortations to accomplish an act, as in 2:6 ("lar tu, fiu al omului, să nu te temi de ei şi nici să nu te pierzi cu firea în faţa lor"), 2:8 ("lar tu, fiu al omului, ascultă-L pe Cel care îţi grăieşte"), 4:1 ("lar tu, fiu al omului, ia-ţi o cărămidă, pune-ţi-o dinainte şi scrijeleşte pe ea cetatea"), 5:1 ("«lar tu, fiu al omului, ia-ţi o sabie <mai> ascuţtĭă decât un brici de bărbier"), 12:3 ("lar tu, fiu al omului, pregăteşte-ţi boccea de robie"), 13:17 ("lar tu, fiu al omului, aţinteşte-ţi faţa împotriva fiicelor poporului tău"), 21:11 ("lar tu, fiu al omului, geme frângându-ţi mijlocul"), 21:19 ("lar tu, fiu al omului, proroceşte şi loveşte-ţi mâinile una de alta şi ia a doua sabie"), 21:24 ("Şi tu, fiu al omului, pregăteşte-ţi două căi <pe care> să intre sabia regelui din Babilon"), 43:10 ("Şi tu, fiu al omului, arată-i casei lui Israel Casa"); or transmit a message, as in 7:2 ("Şi tu, fiu al omului, zi: «Acestea le spune Domnul»"), 21:33 ("Şi tu, fiu al omului, proroceşte şi zi: «Acestea le spune Domnul»"), 28:1 ("lar tu, fiu al omului, spune-i mai-marelui din Tyr: «Acestea le spune Domnul»"), 33:10 ("Şi tu, fiu al omului, spune-i casei lui Israel: «Aşa aţi vorbit»"), 36:1 ("lar tu, fiu al omului, proroceşte împotriva munţilor lui Israel şi spune munţilor lui Israel: "Ascultaţi cuvântul Domnului»"), 39:1 ("Şi tu, fiu al omului, proroceşte împotriva lui Gog şi spune: «Acestea le spune Domnul»"), $39: 17$ ("Şi tu, fiu al omului, zi: «Acestea le spune Domnul»").

\footnotetext{
${ }^{1}$ The examples are quoted, unless a different translation is specified, from Septuaginta (2008).
} 
To this occurrences is to be added the deictic turn of phrase that includes the equivalent of the Greek particle idoú (based on an imperative form), meaning "here you are!", accompanied by a mark of coordination, as in 3:25 ("Şi tu, fiu al omului, iată: ţi s-au pus legători şi te vor lega cu ele").

The sequence /tu+vocative/ might belong to an assertion, as in 33:7 ("Şi tu, fiu al omului, pe tine te-am pus străjer pentru casa lui Israel"), with a mark of coordination. The direct appealing sometimes assumes the interrogative form: 5:2 ("Şi tu, fiu al omului, ce este lemnul viţei faţă de toate lemnele ramurilor care sunt în copacii pădurii?”), 22:2 (“Şi tu, fiu al omului, oare vei judeca cetatea <plină de> sânge?"). As in most of the occurrences previously quoted, there is a mark of coordination before the appellative "son of human". Several interrogations occur inside some fragmented sentences as in 24:25-26 ("lar tu, fiu al omului - oare nu în ziua când iau tăria de la ei [...] în ziua aceea [...]"), 33:30 ("Şi tu, fiu al omului, <iată>, fiii poporului tău grăiesc despre tine [...]").

The inverted order of the words, /vocative+tul, occurs, without the mark of coordination, in 12:2 ("Fiu al omului, tu trăieşti în mijlocul nelegiuirilor acestor <oameni>").

Much more frequent are the occurrences /vocative+[...]/ without the personal pronoun $t u$. There are two distinct developments of the commands in this form, imposing the accomplishment of an act, as in 2:1 ("Fiu al omului, stai pe picioarele tale şi îţi voi grăi"), 2:3 ("Fiu al omului, Eu te trimit"), 3:1 ("Fiu al omului, mănâncă sulul acesta"), 3:3 ("Fiu al omului, gura ta va mânca şi pântecele tău se va umple de sulul acesta"), 3:4 ("Fiu al omului, du-te <şi> mergi către casa lui Israel"), 3:10 ("Fiu al omului, toate cuvintele pe care ţi le-am grăit ia-le în inima ta şi ascultă-le"), 3:17 ("Fiu al omului, team pus străjer pentru casa lui Israel"), 6:2 ("Fiu al omului, aţinteşte-ţ faţa înspre munţii lui Israel"), 8:5 ("Fiu al omului, ridicăţi ochii"), 8:8 ("Fiu al omului, sapă"), 16:2 ("Fiu al omului, dă mărturie lerusalimului"), 20:4 ("Fiu al omului, dă-le lor mărturie"), 21:2 ("Fiu al omului, aţinteşte-ţi faţa împotriva Thaimanului"), 24:2 ("Fiu al omului, scrie-ţi în <fiecare> zi"), 25:2 ("Fiu al omului, aţinteşte-ţi faţa înspre fiii lui Ammon"), 27:2 ("Fiu al omului, porneşte bocet pentru Sor"), 28:12 ("Fiu al omului, porneşte bocet pentru mai-marele Tyrului"), $28: 21$ ("Fiu al omului, aţinteşte-ţi faţa înspre [cetatea] Sidon"), $29: 2$ ("Fiu al omului, aţinteşte-ţi faţa înspre Faraon"), 32:2 ("Fiu al omului, porneşte un bocet pentru faraon"), 32:18 ("Fiu al omului, boceşte pentru tăria Egiptului"), 35:2 ("Fiu al omului, întoarce-ţi faţa spre muntele Seir"), $37: 16$ ("Fiu al omului, ia-ţi un toiag şi scrie pe el"), 38:2 ("Fiu al omului, aţ̧inteşte-ţi faţa înspre Gog şi ţinutul lui Magog"), 44:5 ("Fiu al omului, rânduieşte-ţi în inima ta şi priveşte"); or simply transmitting a message, as in 13:2 ("Fiu al omului, proroceşte împotriva prorocilor lui Israel, proroceşte şi spune-le: [...]"), 17:2 ("Fiu al omului, povesteşte <0> poveste şi spune <0> parabolă pentru casa lui Israel şi zi: [...]"), 17:12 ("Fiu al omului, spune-i casei care <Mă> întărâtă: [...]"), 20:3 ("Fiu al omului, grăieşte-le bătrânilor lui Israel şi spune-le: [...]"), $21: 14$ ("Fiu al omului, profeţeşte şi zi: [...]"), $22: 24$ ("Fiu al omului, spune-i [ţării]: [...]"), 30:2 ("Fiu al omului, proroceşte şi zi: [...]"), 31:2 ("Fiu al omului, spune-i lui Faraon, regele Egiptului, şi mulţimii alor săi: [...]"), 33:2 ("Fiu al omului, grăieşte-le fiilor poporului tău şi spune-le: [...]"), 34:2 ("Fiu al omului, proroceşte împotriva păstorilor lui Israel, proroceşte şi spune-le păstorilor: [...]").

Less frequent are the occurrences of vocative in the middle of the sentence or by the end, $/[\ldots]$, vocative, $[\ldots] /$ or $/[\ldots]$, vocative/, as exhortation to an act, as in 11:4 ("[...] să proroceşti împotriva lor, să proroceşti, fiu al omului."), $20: 27$ ("[...] grăieşte către casa lui Israel, fiu al omului, şi spune-le: [...]”), 21:7 (“[...] să proroceşti, fiu al omului, şi să-ţi aţinteşti faţa împotriva lerusalimului."), 21:17 ("Înalţă strigăt şi jeluieşte-te, fiu al omului, căci <sabia> a ajuns în poporul Meu") and as message to be transmitted, as in 37:9 ("Proroceşte, fiu al omului, proroceşte asupra duhului şi spune-i duhului: [...]"), 38:14 ("[...] proroceşte, fiu al omului, şi spune-i lui Gog: [...]").

The phatic use of vocative is to be found in two coordinates: interrogation versus information, on one hand, and, on the other, the order of words in the sentence. The interrogative pattern of sequence /vocative, [...]?/ occurs in 8:6 ("Fiu al omului, ai văzut ce fac aceştia?"), 8:12 ("Fiu al omului, ai văzut ce fac bătrânii casei lui Israel [...]?"), 8:15 ("Fiu al omului, ai văzut?”), 12:9 (“Fiu al omului, nu ţi-a spus casa lui Israel [...]?"), 12:22 (“Fiu al omului, ce <înseamnă> pentru voi zicala aceasta: [...]?"), 18:2 (“Fiu al omului, ce <înseamnă> pentru voi zicala aceasta: [...]?"); 23:36 ("Fiu al omului, nu le vei judeca oare tu pe Oola şi Ooliba?"), 37:3 ("Fiu al omului, oare vor <mai> fi vii oasele acestea?"). The sequence /[...], vocative?/ occurs in 8:17 (“Ai văzut, fiu al omului?"), 40:4 ("Ai văzut, fiu al omului?"), 43:7 (“Ai văzut, fiu al omului, [...]?"), 47:6 (“Ai văzut, fiu al omului?"). There are relatively frequent occurrences in asserting sentences, type /vocative, $[\ldots] /$, as in 4:16 (“Fiu al omului, iată, Eu voi spulbera [...]”), 11:2 ("Fiu al omului, aceşti [sunt] bărbaţii [...]"), 11:15 ("Fiu al omului, fraţii tăi şi bărbaţii <aflați> cu tine în robie [...]"), 12:2 (“Fiu al omului, tu trăieşti în mijlocul nelegiuirilor acestor <oameni> [...]"), 12:18 ("Fiu al omului, mănâncă-ţi pâinea în durere şi bea-ţi apa în chin şi tulburare."), 14:3 ("Fiu al omului, bărbaţii aceştia şi-au aşezat cugetările [...]"), 14:13 ("Fiu al omului, dacă o ţară păcătuieşte împotriva Mea [...]"), 23.2 ("Fiu al omului, erau două 
femei, fiice ale aceleiaşi mame [...]"), 26:2 ("Fiu al omului, pentru că Sor a vorbit [...]"), 29:18 ("Fiu al omului, Nabucodonosor, regele Babilonului, şi-a pus oastea la trudă grea [...]"), 30:21 ("Fiu al omului, am zdrobit braţele lui Faraon [...]"), 33:24 ("Fiu al omului, cei care locuiesc în ţinuturile pustiite [...]"), $37: 11$ ("Fiu al omului, oasele acestea sunt toată casa lui Israel [...]"), 36:17 ("Fiu al omului, <cei din> casa lui Israel au locuit în ţara lor [...]"), 43:18 ("Fiu al omului, acestea le spune Domnul: $[\ldots]$ ]"), and the type /[...], vocative/, in fragmented sentences, as in 12:27 ("Fiu al omului, iată: casa lui Israel [...]"), 22:18 ("Fiu al omului, iată: <cei din> casa lui Israel [...]"), 24:16 ("Fiu al omului, iată: Eu iau de la tine desfătarea ochilor tăi [...]").

The expected vocative form of this term in Romanian language, fiule ("son") is rarely attested in the old language (vide Bible of Bucharest, 1688), being relatively new. It emerged due to the fact that, simultaneously with the disappearance of the casual desinences, their role was fulfilled by the enclitic article: as soon as the nominal declension faded away, it was replaced by the declension of the article. The immediate advantage on the morphosyntactic level is the presence of a comprehensive paradigm, thanks to the complete series of casual forms. In some distinct conditions, it is obvious that the existence of this desinence (that has a phonetic consistency) has precisely phonetic origins: for the noun fiu, the addition of the vocative desinence directly to the lexical root creates a word that is too short and, implicitly, the final part of the word does not provide enough space for changing the tone (a necessary mark of interpellation): consequently, the enlarged form fiule becomes lexical norm.

The dictionary of the Romanian language (tome II.1, F-I, 1934) registers the sequence Prea bine, fiiule (Calendar 1844). The regular Latin inherited form, fii, is frequently used by Coresi; the old writings, on the other hand, attest the vocative fiule. All the same, the Coresi texts display nominative occurrences of this term with vocative function ("Fiu, lasă-ti-se păcatele tale"); in contemporary language, it occurs with this function only when accompanied by the possessive adjective: fiul meu.

The Romanian language preserves some specific vocative desinences, consistent with the general trend of linguistic conservatism in the frame of Romance languages. Among the vocative desinences, some are inherited from Latin, probably as a result of Slavic enforcement (e.g. -e in masculine singular), some others are borrowed from Slavic (the feminine singular -o) and others are created in Romanian language: masculine singular -ule, coined on the enclitic article, masculine singular, - $(u)$ l, enlarged with the specific vocative desinence, resulting in a complete paradigm of the masculine declension (with article), differentiating the cases of the singular (nominative-accusative: -ul, genitive-dative: -ului, vocative: -ule), nonetheless the vocative plural form, both in masculine and feminine nouns, -lor, formed by reusing the desinence for genitive-dative plural, with article, of the masculine nouns. The usual explanation for this astonishing form is a reinterpretation of the religious phrase "Vă spun vouă, fraţilor", "I tell you, brothers", throughout a gradual shift of dative to vocative, probably as a result of the fact that the concorded apposition (in dative case, in this example) became weak and finally disappeared.

There are circumstances (vide Vasiliu, 1956, 12-15) when both forms $(-e,-u l e)$ are preserved, with basically no differences of their meaning; there are solely some fine distinctions, brought by a certain affectivity attached to one of the forms, expressing irony, despise, hypocoristic appellation, e.g. the vocative forms of the nouns copil, băiat , poet ( "child", "boy", "poet"). Some old terms are preserved only with the enlarged vocative form, which totally replaced the previous one, as in bât ("grandfather", a restricted term) or unchi ("oncle"): bâtule and unchiule replaced bâte and unche.

Words sharing the same vocative syntactic status (Vasiliu, 1956, 21) display either one single vocative desinence, or as many as words are; the multiplication of vocative morphological marks is more frequent in colloquial language, e.g. sărmane omule (Ion Creangă), nene lancule (Ion Luca Caragiale), cinstitilor negustori (Mihail Sadoveanu), nevertheless some old texts, e.g. iubite cetitoriule (Miron Costin, the Moldavian chronicler).

The preservation of vocative in Romanian language is fortified by the emergence of new morphological marks, well attested along the linguistic history. Despite the general tendency toward simplifying the nominal paradigm, by reducing as much as possible the differences between the actual two cases of the Romanian language (nominative-accusative and genitivedative), the presence of vocative case seems to get stronger, not only syntactically, but also morphologically. This surprising

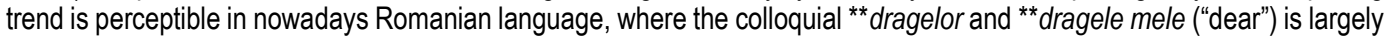
used as a feminine counterpart of dragilor and dragii mei, the correct form of vocative plural, both for masculine and feminine. 
The conclusion is double: Romanian language attests, like most Romance (and also Indo-European) languages, a shift from vocative toward nominative, id est providing a nominative form with a vocative function; on the other hand, although the nominal flexion tends to diminish, there is attested a multiplication of vocative marks, even though in linguistic conditions that are not yet accepted by the norm.

\section{Bibliography}

[1] Avram, Mioara (1986): Gramatica pentru toţi, Bucharest, Romania: Editura Academiei.

[2] Dan, llie (1964): Discuţii asupra vocativului românesc. Analele ştiinţifice ale Universităţii «Al. I. Cuza» din laşi, X, 1, 1-13.

[3] Graur, Alexandru (1936): Influence de vocatif sur le nominative. Bulletin linguistique, Paris-Bucarest, IV, 194-196.

[4] Pană Dindelegan, Gabriela (2010): Gabriela Pană Dindelegan (coord.), Adina Dragomirescu, Isabela Nedelcu, Alexandru Nicolae, Marina Rădulescu Sala, Rodica Zafiu, Gramatica de bază a limbii române, Bucharest, Romania: Univers Enciclopedic Gold.

[5] Puşcariu, Sextil (1976): Limba română. I. Privire generală, Bucharest, Romania: Fundaţia pentru Literatură şi Artă.

[6] Septuaginta (2008): Septuaginta 6/II, C. Bădiliţă, F. Băltăceanu, M. Broşteanu (ed.), I. Costa, F. Bechet (translation, commentaries), lasi-Bucharest, Romania: Polirom-NEC.

[7] Sluşanschi, Dan (1994): Sintaxa limbii latine, I, Bucharest, Romania: Editura Universităţii din Bucureşti.

[8] Tomescu, Domniţa (1998): Gramatica numelor proprii în limba romana, Bucharest, Romania: Editura All.

[9] Vasiliu, Laura (1956): Observaţii asupra vocativului in limba română, Studii de gramatică, I, Bucharest, 5-23.

[10] Zimmerli, Walther (ed.) (1969): Ezechiel, Neukirchen-Vluyn, Germany: Neukirchener Verlag des Erziehungsvereins. 